\title{
THE REFUGEE CRISIS AFFECTING EU FOREIGN AND SECURITY POLICY
}

\author{
Elena Tilovska-Kechedji * \\ ${ }^{1}$ Assistant Professor Ph.D., University "Clement Ohridski” - Bitola, Macedonia, elena-tilovska- \\ kechegi@hotmail.com
}

\begin{abstract}
The conflict in Syria has started the largest refugee crisis since World War II. Syria is a country with around 22 million people, from this number with the start of the Syrian civil war, 200,000 people have been killed including 8000 children, 7.6 million are internally displaced people, 3.2 million are refugees and 12.2 million people are in need of humanitarian aid. These enormous numbers have had an impact not only on the neighboring countries of Syria like Jordan, Lebanon, Turkey but also the impact was enormous on the European Union countries and on the international community. The critical challenges and the areas of intervention from the international community and the EU are legal and physical protection, providing shelters, health, education and employment for the refugees. These are not the only obstacles of the refugee crisis there is the economic, political and social and the security pressures. For all these obstacles the solutions are, all the EU countries should work together to help the refugees with the creation of improved legal and institutional framework for asylum and migration, the EU must resolve the inadequacies of Dublin that regulates the entry of migrants and redefine the human rights implications and also reinforce the security policies in order to stop or prevent the emergence of nationalist or racist movements and terrorist attacks.
\end{abstract}

Keywords: Refugee crisis, Syria conflict, EU, foreign and security policy.

\section{INTRODUCTION TO THE CONFLICT IN SYRIA}

Syria since 1966 has been experiencing a repressive military coup from the autocratic Baath party. In 2000, a new leader came on power Bashar al-Assad, with a promise of political and economic reform which was not kept. There was a liberalization of the national economy that led to economic growth but only the regime and the new president benefited from that economic growth. Furthermore, in 2011 begun peaceful protests, with democratic aspirations, that were led by the Arab spring but they were brutally stopped by the regime. (Elements for an EU regional strategy for Syria and Iraq as well as the Da'esh threat, 2015, pp. 3-4) The opposition fought back and the violence escalated so the country fell into a civil war. By June 2013, 90,000 people were killed and that number doubled by the end of the next year. The civil war in Syria today is no longer the battle between those that are for the government and against, the conflict had a spillover effect in 
neighboring countries, there was a rise of the jihadist groups and the Islamic State. (Syria: the story of the conflict, 2015, pp.1-4)

The terror that has been going on in Syria and the neighboring countries is unthinkable. The militants should be punished for committing war crimes that include torture, rape, murders, civilian sufferings, deliberate massacres and the use of toxic chemical weapons. And to add to this terror Da'esh (Islamic State of Iraq and the Levant whose acronym is Da'esh) has been further terrorizing the people in northern and western Syria. (Syria: The story of the conflict, 2015, p. 9) Da'esh is situated across two states with an intent to act as a state itself. Its terrorist, criminal and military actions lead to an insurgency. Their enforcement in Syria led to crimes against humanity and war crimes. All of these has led to population displacement, trauma inflicted on women and children, and massive influx of refugees. (Elements for an EU regional strategy for Syria and Iraq as well as the Da'esh threat, 2015, pp. 4-5). Due to all of the above more than four million people have left Syria which is the largest refugee exile since World War II.

\section{THE REFUGEE CRISIS}

The meaning of the term migrant is a person moving to another country with the intention of staying in that country for a short period of time. But there is long-term migrant who moves to a country with the intention of staying in that country for a longer period. The Asylum seeker is a person who has submitted a request for asylum but it has not yet completed the asylum procedure. The humanitarian migrants have completed the asylum procedure and have been granted protection and the refugee status. (Is this humanitarian migration crisis different? 2015, p.4) An economic migrant is a person who seeks asylum for economic gain. (Park, J. $2015, p .2)$ All of these definitions will help us understand not only the meaning of the terms given above but it will help us understand the crisis itself.

The refugee crisis is a result of the conflicts in disturbed countries, civil wars, horrible violations of the human rights. After World War II, the United Nations Refugee Convention was created, in order to help and protect the refugees and help the countries to cope with the crisis. 145 countries have ratified the Convention but many countries from the Middle East and Asia did not do so. But the fact that these countries have ratified the convention does not give any assurance that they will help or act in today's global crisis. (The Global Refugee Crisis: A conspiracy of neglect, 2015, p. 31)

The refugee crisis cannot be solved unless the international community wants to intervene. The definitions given above for refugees are in order to present the picture that these people do not have the protection of their country nor their homes because the state can no longer provide protection willingly or unwillingly. These people suffered armed conflicts, persecutions, dreadful violence, massacres and human rights abuses and that is why they left their countries and their homes and became refugees. (The Global Refugee Crisis: A conspiracy of neglect, $2015, p .7)$ Of course, there is always the possibility that not all the refugees are victims looking for a safe ground, there is the possibility of economic migrants and infiltrating of terrorists.

\subsection{The Refugee Crisis in the Neighboring Countries}

There are four million Syrian refugees living in the neighboring countries and the broader region. Lebanon hosts 1.2 million refugees from Syria, Jordan hosts 627,287 Syrian refugees and 7.6 million people are internally displaced inside Syria. The Syrian crisis has posed strains on all factors of life like shortage of food and other supplies even inside the neighboring countries, therefore, Jordan has imposed restrictions on Syrian refugees. Lebanon closed the borders in January 2015, Iraq hosts 248,367 Syrians and the borders are closed only in the non-conflict zones and Syrians have the right to cross the borders with a 15-day visa. Turkey hosts the largest number of refugees more than 1.7 million, although it still has the open door policy, since 2012 it closed almost all its borders because of security issues. Furthermore, Egypt host 134,329 Syrian refugees and in 2013 the authorities posed a visa regime. The lack of options for the Syrian refugees leads them to use the sea voyages across the Mediterranean to seek a better life in Europe and in the US. (The Global Refugee Crisis: A conspiracy of neglect, 2015, pp. 10-16)

\subsubsection{The Death Routes on the Way to Europe}

In 2014, 219,000 refugees tried to cross the Mediterranean Sea and only 141,000 made the shore of Italy. The Mediterranean route is the most dangerous sea route because the refugees travel in unsafe vessels. In 2013, the Italian government started a naval operation called Mare Nostrum in order to help the refugees but some states did not want this operation because it acted as a "pull- factor" for refugees and therefore Italy in 2014 stopped the operation. After this operation, the EU Border agency created the Frontex to start the operation Triton but not to help the migrants but to control the borders. After the end of Mare Nostrum, there was a dramatic increase in deaths. (The Global Refugee Crisis: A conspiracy of neglect, 2015, pp. 17-22) 
The refugees continued to use other routes in order to leave Syria and the other neighboring countries and seek a better life in Europe.

In 2015, The Eastern Mediterranean route and the Western Balkan route, from Turkey to Greece were used by around 66,000 refugees. The Central Mediterranean route from Libya to Italy was used by 116,000 refugees in the period of August 2015. The Western Mediterranean channel goes through the Spanish Ceuta and Melilla or through the Strait of Gibraltar. This route was not used as much by Syrians but more by subSaharan migrants. Italy, Greece, and Turkey are the first countries of arrival but they are seen as transit countries because the refugees want to settle further in the west of Europe. (Is this humanitarian migration crisis different? 2015, pp. 3-4)

\section{EUROPE'S REACTION TO THE CRISIS AND THE EFFECTS ON EU FOREIGN AND SECURITY POLICY}

\subsection{The Creation Of The Asylum Policy}

In 1990 with the Dublin Agreement was created the asylum policy of the European Union. One of its key principles is that the state in which the migrant entered should be the one that processes the asylum application. This principle was intended to prevent the refugees from applying in several states at the same time and prevent the states from giving their responsibility for the refugee to another state. Furthermore, in 1997 with the signing of the Amsterdam Treaty, the member states agreed to address the aspects of asylum together. In 1999, the European Council approved the European Asylum System that is based on the Geneva Convention on the Status of Refugees. Since then several directives have been adopted like the Reception Condition Directive in 2003 that presents the base for reception and housing of the refugee. The Asylum Qualification Directive in 2004 establishing minimum standards for recognition of asylum seekers. And in 2005 was proposed the Asylum Procedures Directive with the aim of harmonizing the asylum procedures. In the meantime, a Refugee Fund was set to assist member states and the refugees. To continue with, in 2000 the Eurodac Regulation was adopted to help the Dublin Mechanism workable, it provides the fingerprints of all asylum seekers to be accessible in all EU database. But the Dublin system did not function as it should because states received different numbers of asylum seekers, different standards continued to be applied between states. Due to these problems in 2008, the EU decided on the European Pact on Immigration and Asylum and a creation of a European Asylum Office (EASO) in order to stabilize the standards for refugees. In 2015, a Common European Asylum System (CEAS) was created for better access to asylum procedures, faster and fairer decisions and better conditions for refugees. (Angenendt, Engler, Schneider, 2013, pp. 1-4) All of the reforms in the Dublin regulation (Dublin II and III) were a step towards establishing a common European Asylum policy. But these steps do not prove that the European Asylum policy will work because so far all of the measures that are taken and the steps that were explained above did not work because the EU countries cannot find a common language on how to apply the Asylum policy. The opinions and the attitudes towards the crisis are not unanimous.

\subsection{Managing the Crisis}

Migration should be seen as a human security issue, not as a national security issue and the problems should be solved in several steps. First, the EU must take care of the refugees and help save lives. In September 2015, the member states agreed to resettle 120,000 migrants from Greece and Italy to the other twenty-three states. (Park, J. 2015, pp. 4-5) The idea of resettling the refugees among states is not the only mechanism, the Commission has also proposed an EU list of safe countries of origin which means that these countries meet the basic Copenhagen criteria for EU membership and are applicant states, not member states. (Migration into the EU - a first look at the impact, 2015, pp. 4-5).

As a second step in helping the crisis, the EU has provided 230 million euros in humanitarian and other assistance inside and outside Syria. But the aid is only part of the EU response to the Syrian political and humanitarian crisis. The EU tried to bring political transformation in Syria, by removing the authoritarian regime and stopping the violence. The steps taken by the EU are through the economic sanctions and other restrictive measures and by terminating the EU-Syrian bilateral communications and giving support to the opposition movements. (Fargues, P. \& Fandrich, C. 2012, pp. 8-13)

As long as there are conflicts in the neighborhood the flow of refugees will continue even if the system changes in Syria. Therefore, the European Union must present a strong position towards the crisis and start this actions:

- Establish a Regional Protection Program (RPP) with a large increase of Syrian refugee resettlement as a required component; 
- Increase refugee resettlement for those who have been affected by the Syrian crisis and are the most in need;

- Continue positive asylum procedures throughout the EU, and grant prima facie recognition including provision of sufficient assistance;

- Encourage visa facilitation and family reunification for Syrians;

- Continue to work with its international partners to find a political and humanitarian solution to the Syrian crisis.

(Fargues, P. \& Fandrich, C. 2012 p. 14)

Furthermore, the EU should:

- Save lives at sea with sustained search and rescue operations;

- Ensure that the passengers are not being used for human trafficking ad smuggling;

- Increase safe and legal channels to enter the EU;

- Adequate reception conditions by EU law. (Europe's Refugee Crisis 2015, pp. 3-4)

Also, there should be a differentiation between a migrant and Islamist terrorist a suspicion that was increased during the Madrid bombings in 2004, the London bombings in 2005, the bombings in Paris and the bombings in Turkey and in Brussels in March 2016. The EU external policy influences the internal security policy through its weakness.

\subsection{EU Unprepared To Deal with the Crisis}

The Foreign Affairs and Security Policy is leading towards making the neighborhood of the European Union a priority for the European External Action Service (EEAS) in order to promote safety and stability. Syria is part of the European Neighborhood Policy (ENP). The European External Action Service (EEAS) was created to support stability, promote human rights, democracy and prosperity, the rule of law and good governance. With the Lisbon treaty, the EU foreign policy was changed in order to promote unity inside the Union so there is a political weight to its decisions and the EEAS was created to achieve that goal. But after analyzing the Syria's conflict the member states did not share a common stand, did not have a comprehensive strategy and the EU missed its opportunity to affirm itself as a foreign policy actor. The European Union actions in Syria were presented through declarations and sanctions, support for the political opposition, military support and military intervention. The EU froze the financial and technical assistance programs, sanctioned the trade with the oil industry and it imposed an arms embargo. Furthermore, in the diplomatic field the EU played a supportive role rather than an active role in the mediation. Despite the improvements made in its foreign policy, in the Syrian case, the EU did not stay consistent, coherent and effective in its external actions. It lacked a strategy on how to deal with the crisis. The EU wanted to keep the diplomatic dialogue between the Syrian conflicting parties in Geneva but it stood more as a neutral mediator and the interventions were left to the UN, US, and Russia. And this is all thanks to the incompatible foreign policy system and the lack of leadership of the EEAS. (Dialer, D. Neisser, H. Opitz, A. 2014, pp.145-162)

Up till now the conclusions are obvious on how the EU stands in response to any kind of crisis. The crisis management is one of the tools of EU foreign policy but it is very poor. (Dempsy, J. 2015, p.1) The EU Common Security and Defense Policy (CSDP) should work on strategy and power politics but there should be coordination between the internal and external security. Like Frontex (EU EXTERNAL BORDER AGENCY) that works in order to improve the coordination between the military and police on securing the EU from the Islamic state of Iraq and the Levant and managing the external borders. The CSDP must develop a specific concept on the refugee crisis and use its policy tools through diplomacy, development, and trade. The CSDP expertise should be used to help the regional politics. (Parkes, R. 2014, pp. 14-16) Its expertise should be used not only to prevent further escalation of the crisis but it should be used to prevent other dangerous situations.

\section{CONCLUSION}

The global refugee crisis that we are all facing today is a result of wars and terrible human rights violations. Addressing the policies of asylum and security, the response to the crisis and tackling the racism towards the refugees is difficult for the European Union. The European Union did not stay consistent and effective in its external actions. It lacked and still lacks the strategy on how to deal with the crisis. The EU needs to coordinate its actions in order to regain its status in the international community. The EU aims should be to 
support a political solution to the Syrian crisis, prevent regional destabilization, address the humanitarian situation and address the conflict outside and inside the EU. The way it addresses this crisis it will present whether it will live up to its principles of human dignity, solidarity, freedom .and democracy.

\section{REFERENCE LIST}

Angenendt, S. Engler, M. Schneider, J. (2013). European

Refugee Policy, Pathways to Fairer Burden-Sharing. General Institute for International and Security Affairs. https://www.swp-berlin.org/fileadmin/contents/products/comments/2013C36 adt engler schneider.pdf

Dialer, D. Neisser, H. Opitz, A. (2014) The EU's external action

service. Potential's for one voice foreign policy EUROPAWISSENSCHAFTLICHE REIHE, BAND 3. Innsbruck University press http://www.uibk.ac.at/iup/buch pdfs/eeas bd3.pdf

Dempsey, J. (2015). What Europe's Refugee Influx Means for

EU Foreign Policy. CARNEGIE EUROPE. http://carnegieeurope.eu/strategiceurope/?fa=61080

Elements for an EU regional strategy for Syria and Iraq as well as

The Da'esh threat. J (2015) JOINT COMMUNICATIONS TO THE EUROPEAN PARLIAMENT AND THE COUNCIL. JOIN (2015)2 final. http://ec.europa.eu/echo/files/news/20150206 JOIN en.pdf

Europe's Refugee Crisis. An Agenda for Action. (2015). Human

Rights Watch. https://www.hrw.org/report/2015/11/16/europes-refugee-crisis/agenda-action

Fargues, P. \& Fandrich, C. (2012). The European Response to the

Syrian Refugee Crisis What Next? European University Institute. Robert Schuman Centre for Advanced Studies. http://www.migrationpolicycentre.eu/docs/MPC\%202012\%2014.pdf

Is this humanitarian migration crisis different? (2015) Migration

Policy Debates. No.7, September 2015 http://www.oecd.org/migration/ls-this-refugee-crisis-different.pdf

Park, Jeanne. (2015). Europe's Migration Crisis. Council of Foreign

Relations http://www.cfr.org/migration/europes-migration-crisis/p32874

Parkes, R. (2014). Integrating EU defense and migration policies in

the Mediterranean. FRIDE No. 125

http://fride.org/download/WP 125 Integrating EU defence and migration policies in the Mediterra nean.pdf

Migration into the EU- a first look at impact. (2015). Deutsche Bank

Research. https://www.dbresearch.com/PROD/DBR INTERNET ENPROD/PROD0000000000364625/Migration into the EU - a first look at the impact.pdf

Syria: The story of the conflict. (2015). BBC.

http://www.bbc.com/news/world-middle-east-26116868

The Global Refugee Crisis: A conspiracy of neglect. (2015). Amnesty

International, POL40/1796/2015 https://www.amnesty.org/en/documents/pol40/1796/2015/en/ 